\title{
First Record of Epibionts Peritrichids and Suctorians (Protozoa, Ciliophora) on Pomacea lineata (Spix, 1827)
}

\author{
Roberto Júnio Pedroso Dias ${ }^{1 *}$, Sthefane D`Ávila ${ }^{2}$ and Marta D`Agosto ${ }^{3}$ \\ ${ }^{1}$ Universidade Federal de Juiz de Fora; Instituto de Ciências Biológicas; Programa de Pós-graduação em Ciências \\ Biológicas, Comportamento e Biologia Animal; Bolsista CAPES; rjuniodias@yahoo.com.br; ${ }^{2}$ Universidade \\ Federal Rural do Rio de Janeiro; Parasitologia Veterinária; Programa de Pós-graduação em Ciências Veterinária; \\ Bolsista CNPq; sthefanedavila@hotmail.com ${ }^{3}$ Universidade Federal de Juiz de Fora; Instituto de Ciências \\ Biológicas; Departamento de Zoologia; dagosto@icb.ufjf.br; Campus Universitário; 36036-330; Juiz de Fora-MG- \\ Brasil.
}

\begin{abstract}
This study made a survey on the ciliate protozoans from Peritrichid and Suctorian taxa, epibionts of Pomacea lineata (Spix, 1827) (Ampullariidae). Fifty mollusks were collected in places of irrigation ditches and shell was scraped with a scalpel and the extracted material was analyzed in vivo by light microscopy. All examined mollusks presented epibiont ciliates on their shells. For the first time epibiont ciliates in P. lineata was record. Seven genera of ciliates: two peritrichids and five suctorians, were identified and classified within the subclass Peritrichia: Carchesium Ehrenberg, 1838 (Vorticellidae), Epistylis Ehrenberg, 1830 (Epistylidae), Opercularia Stein, 1854 (Operculariidae), Vaginicola Lamarck, 1816 (Vaginicolidae) and Vorticella Linnaeus, 1767 (Vorticellidae); and Suctoria: Acineta Ehrenberg,1834 (Acinetidae) and Tokophrya Bütschli,1889 (Tokophrydae). The results showed that P. lineata constitute the microenvironment of a ciliate protozoan community that presents complex trophic interactions.
\end{abstract}

Key words: Epizoic ciliates, prosobranch snail, freshwater environment

\section{INTRODUCTION}

Several ciliate protozoans live as epibionts on animals and plants, using them as substrate (Sleigh, 1979; Dragesco and Dragesco-Kernéis, 1986; Fenchel, 1987). This association involves specialized groups such as peritrichids and suctorians, which occur in a variety or strict range of hosts. The associations may not be obligatory, and the epizoic communities are generally characterized by a high number of species which may occupy very specialized niches (Fenchel, 1987). Although most of these ciliate protozoans are not harmful to their hosts, in high densities they can interfere in host's mobility (Görtz, 1996), or cause stress, which makes the host more suceptible to contaminants and possibly other natural stressors such as food limitation (Puckett and Carman, 2002). Epibiont ciliates can live on several metazoan species, including cnidarians, ctenophores, rotifers, annelid worms, crustaceans, insect larvae, mollusks, fishes and tadpoles (Henebry and Ridgeway, 1979; Görtz, 1996; Foissner et al., 1999; Moss et al., 2001). Several authors have emphasized the lack of studies about the distribution and the occurrence of ciliate protozoans associated with freshwater organisms

\footnotetext{
${ }^{*}$ Author for correspondence
} 
in natural conditions, as well as the lack of information on the ecology and the interactions between epibionts and hosts (Fernández-Leborans et al., 1997; Aladro-Lubel and Martínez-Murillo, 1999; Mayén-Estrada and Aladro-Lubel, 2001). This study aimed to survey Peritrichid and Suctorian ciliates, epibionts on Pomacea lineata (Spix, 1827) (Ampullariidae).

\section{MATERIAL AND METHODS}

Fifty mollusks were collected in places of irrigation ditches at Granjas Irmãos Fernandes under the geographical coordinates of $21^{\circ} 39^{\prime} 6$ " S and $43^{\circ} 25^{\prime} 54^{\prime}$ 'W, Juiz de Fora county, state of Minas Gerais, Brazil. In this locality several pesticides such as herbicides, pyrethroids, fungicides, organophosphorate insecticides, molluscicides and acaricides are used (Cardoso et al., 2001). In order to examine epibionts, mollusk's shell was scraped with a scalpel. The extracted material was analyzed in vivo using bright field and phase contrast microscopy. Two preparations of each mollusk were analyzed, totaling up 100 preparations.

\section{RESULTS AND DISCUSSION}

All examined mollusks presented epibiont ciliates on their shells. Seven genera of ciliates: two peritrichids and five suctorians, were identified and classified according to Lynn and Small (2002) (Table 1).

Table 1 - Protist ciliates epibionts on Pomacea lineta Spix, 1827

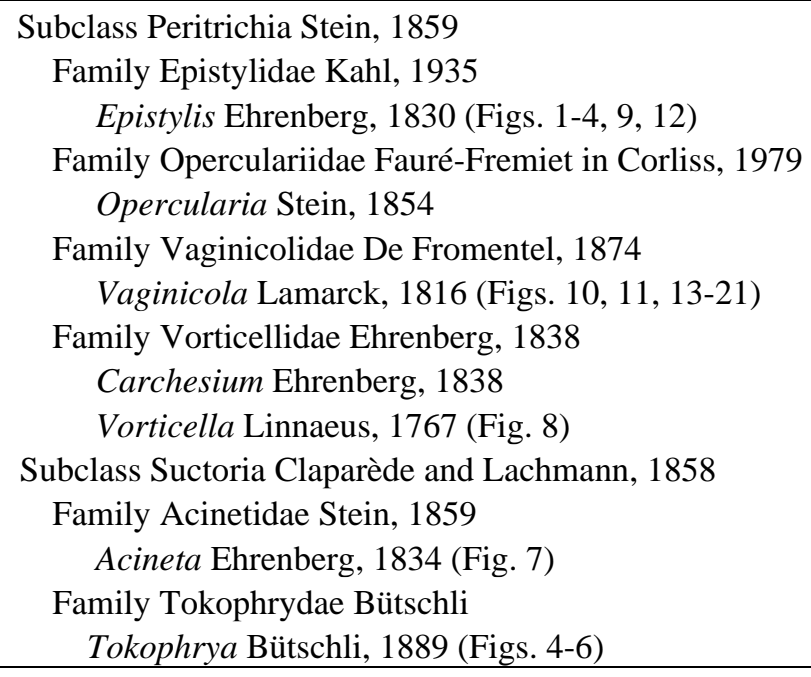

Ciliates in the subclass Peritrichia provided many examples of epizoic way of life, living over planktonic and benthonic metazoans both in marine and freshwater environments (Corliss, 1979; Puytorac, 1994; Foissner et al., 1999). The sessile way of life and the colonial organization showed by peritrichids were among their main characteristics. Among peritrichids' adaptations to the epizoic way of life was the free-swimming stage (telotrochs) in which they were able to establish colonies on new hosts (Fenchel, 1987).

Protozoans in the Suctoria subclass are deprived of cilia or other locomotory organelles in their adult stage. They did not present oral opening, using tentacles to capture their preys (Puytorac, 1994). Suctorians are very common both in marine and freshwater environments, frequently as epibionts on a variety of animals (Foissner et al., 1999). These protozoans attach to their hosts directly or by using stalks, and they feed mainly on other ciliates (Verni and Gualtieri, 1997). Among epibiont suctorians, a hard competition could exist, as was observed by Mayén-Estrada and AladroLubel (2001) for Acineta tuberosa Ehrenberg, 1838; Podophrya sandi Collin, 1911 and Tokophrya quadripartita (Claparède and Lachmann, 1859) Bütschli, 1889. 


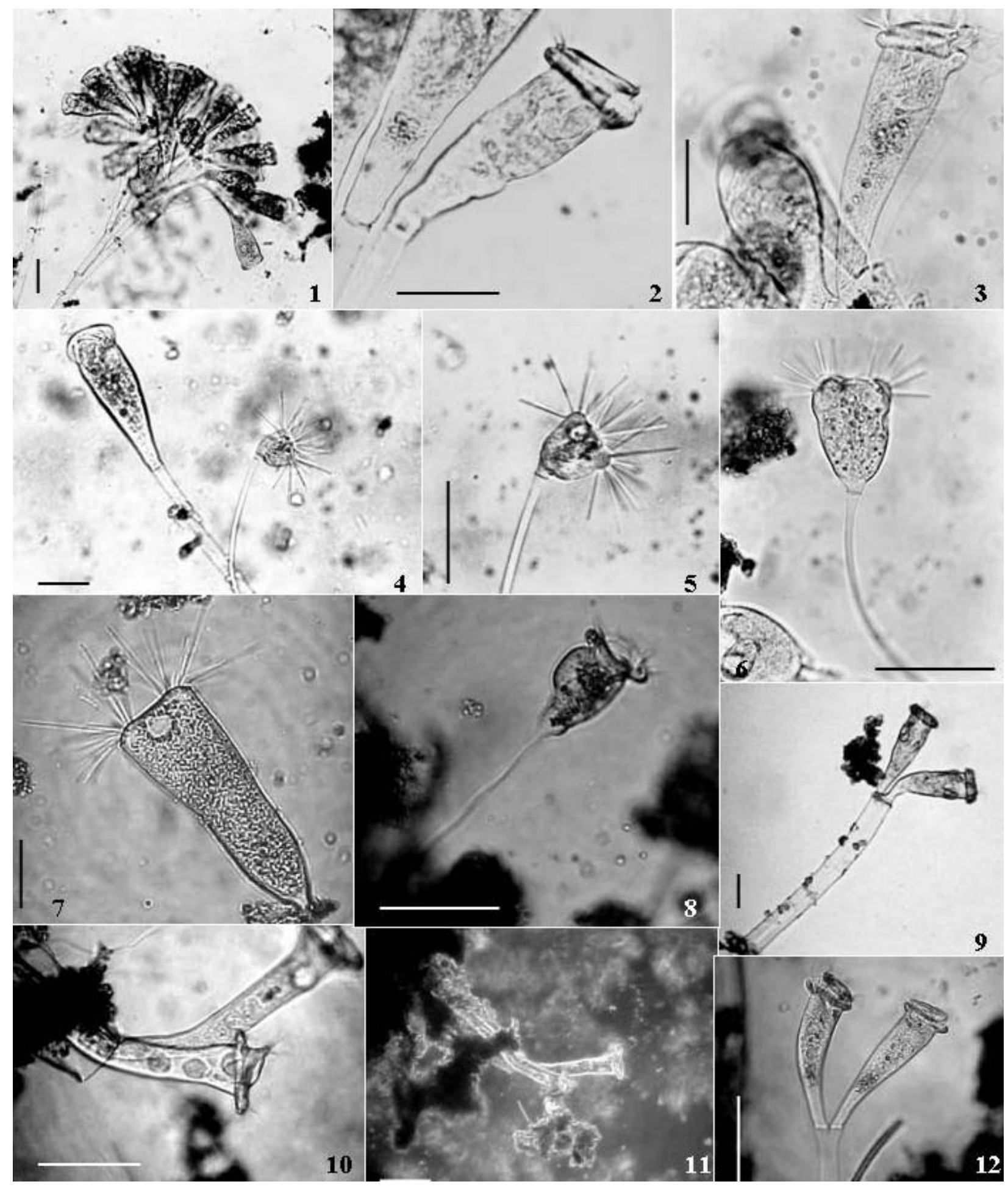

Figures 1-12 - Epibiont ciliates on Pomacea lineata (Spix) (Ampullariidae). 1-3, 9, 12. Epistylis spp. (Epistylidae) (peritrich); 4. Epistylis sp. (peritrich) as a substrate to Tokophrya sp. 1 (Tokophrydae) (suctorian). 5. Tokophrya sp. 1. 6. Tokophrya sp. 2. 7. Acineta sp. (Acinetidae) (suctorian). 8. Vorticella sp. (Vorticellidae) (peritrich). 10-11. Vaginicola sp. (Vaginicolidae) (peritrich) in vivo. Bars $=50 \mu \mathrm{m}$. 


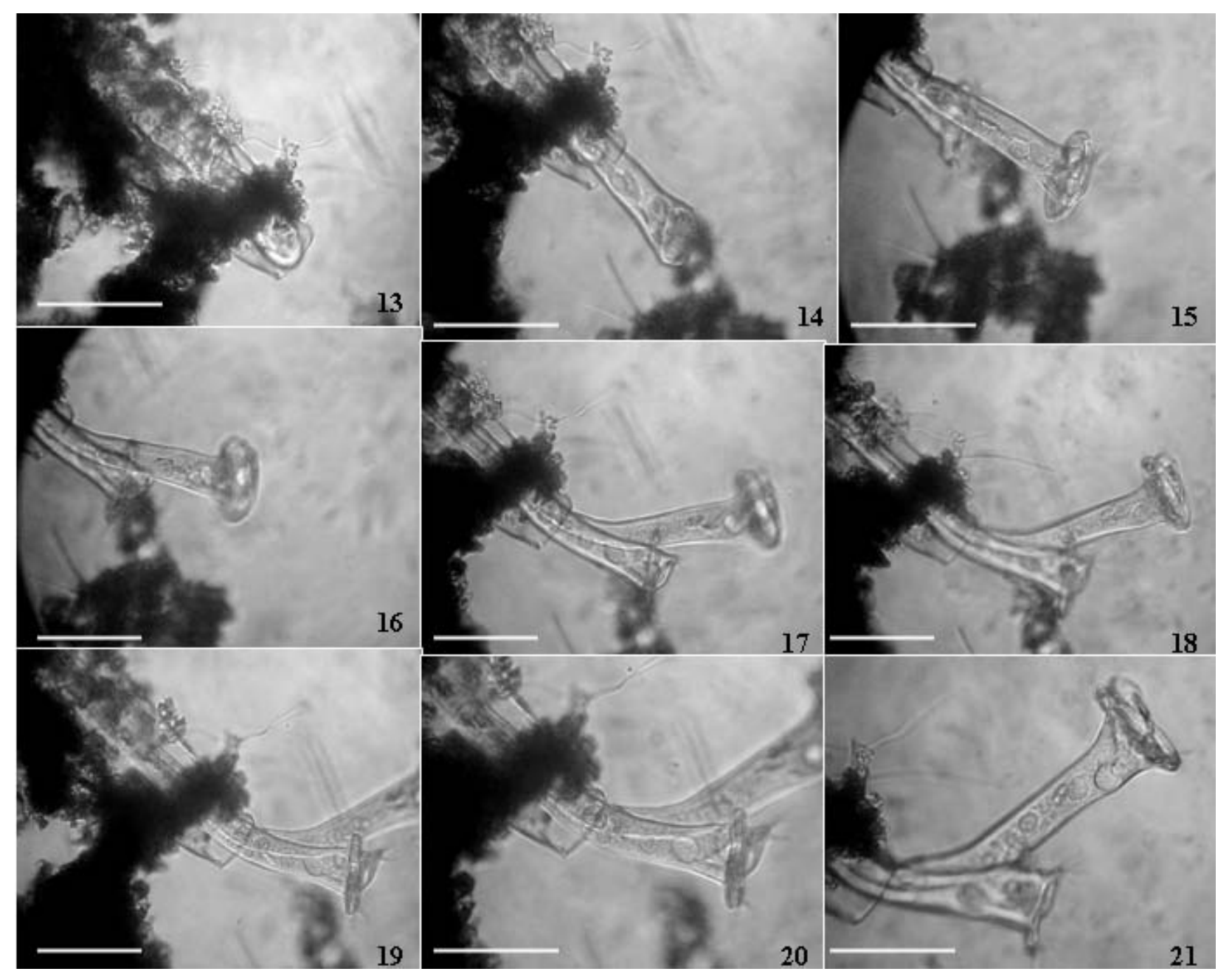

Figures 13-21 - Ciliate epibiont Vaginicola sp. (Vaginicolidae) coming out of the lorica. Bars $=50 \mu \mathrm{m}$.
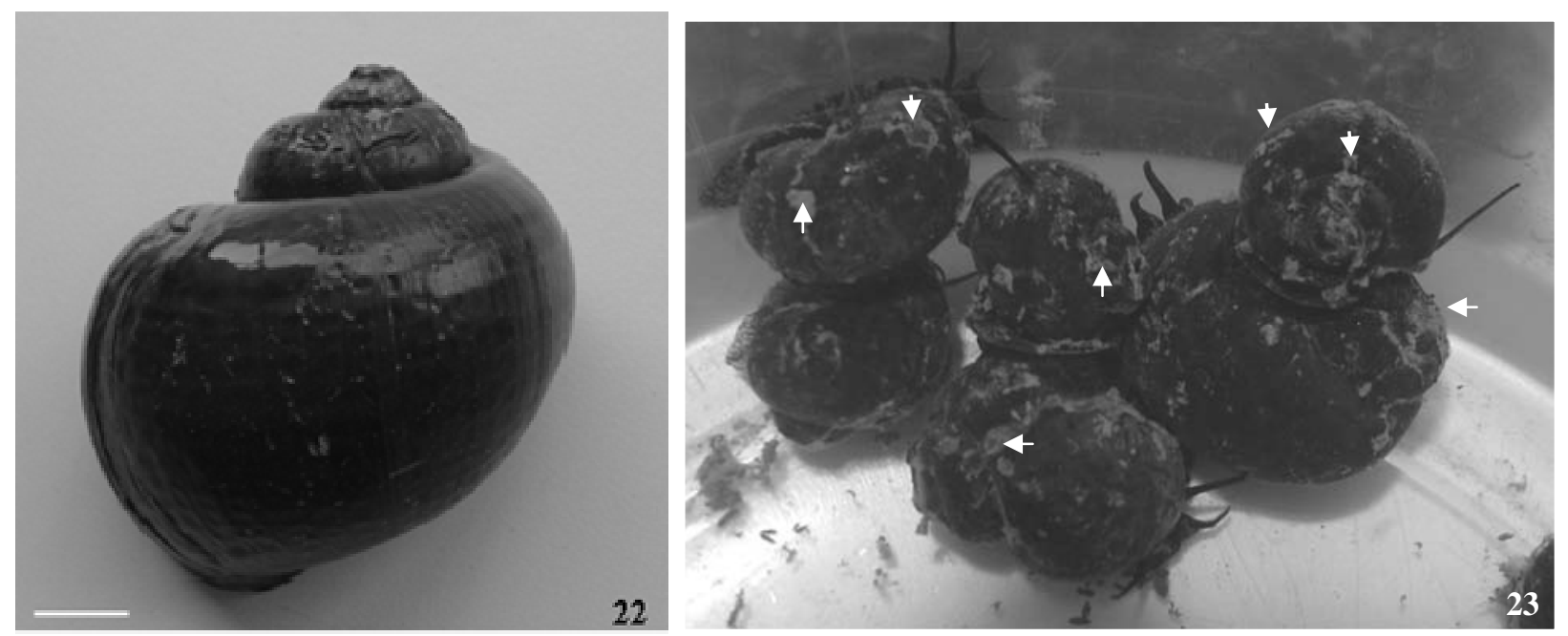

Figures 22-23 - Pomacea lineata (Spix 1827). 22. Shell of Pomacea lineata. 23. Aggregative behaviour of Pomacea lineata. The arrows show the accumulation of algae and bacteria the place where the ciliates live . Bar $=1 \mathrm{~cm}$. 
The frequent occurrence of ciliate epibionts observed in the current study might have been favored by the host behavior, such as its preference for places abundant with food, their gregarious behavior and their attempt to avoid adverse environmental conditions or fatal events such as desication or the grazing of its surface by animals as suggested by Fenchel (1987).

The mollusk's shell was a substrate in which there was an accumulation of algae and bacteria (Figs. 22,23 ), which were used as food by ciliate species of peritrichids, which are food for predator ciliates of suctorians. Therefore, $P$. lineata constituted the microenvironment of a ciliate protozoan community that presents complex trophic interactions.

\section{ACKOWLEDGEMENTS}

We would like to thank Mr. Alceu Coutinho Dias for his logistic support and to PhD Laura Utz (UFRGS) for the identification of some genus of ciliates.

\section{RESUMO}

O objetivo do presente estudo foi realizar um levantamento dos protozoários ciliados dos táxons Peritrichia e Suctoria, epibiontes de Pomacea lineata (Spix, 1827) (Ampullariidae). Cinqüenta moluscos foram coletados em ambientes de vala de irrigação, em Juiz de Fora, Minas Gerais. As conchas dos moluscos foram raspadas com bisturi e o material extraído analisado in vivo sob o microscópio de luz. Todos os moluscos examinados apresentaram ciliados epibiontes em suas conchas. Registra-se pela primeira vez ciliados epibiontes em $P$. lineata. Sete gêneros de ciliados: dois peritríquios e cinco suctórios foram identificados e classificados nas subclasses Peritrichia: Carchesium Ehrenberg, 1838 (Vorticellidae), Epistylis Ehrenberg, 1830 (Epistylidae), Opercularia Stein, 1854 (Operculariidae), Vaginicola Lamarck, 1816 (Vaginicolidae) e Vorticella Lìnnaeus, 1767 (Vorticellidae); e Suctoria: Acineta Ehrenberg, 1834 (Acinetidae) e Tokophrya Bütschli, 1889 (Tokophrydae). Os resultados deste estudo demonstraram que $P$. lineata constitui o microambiente de uma comunidade de protozoários ciliados que exibem interações tróficas complexas.

\section{REFERENCES}

Aladro-Lubel, M. A. and Martinez-Murillo, M. E. (1999), Epibiotic Protozoa (Ciliophora) on a community of Thalassia testudinum banks ex König in a coral reef in Veracruz, Mexico. Aquat. Bot., 65, 239-254.

Cardoso, R. N.; Nascimento, H. F.; Alves, H. F. C.; Costa, G. P. and Castro, G. A. (2001), Bifid labial palp in Pomacea lineata (Spix, 1827) Mollusca, Gastropoda, Ampullariidae). Rev. Bras. Zoociências, 3 : (2), 239-242.

Corliss, J. O. (1979), The ciliated protozoa. Characterizaton, classification and guide to the litherature. New York, Toronto, Sidney, Paris: Oxford. 455 pp.

Dragesco, J. and Dragesco-Kernéis A. (1986), Ciliés libres de l'Afrique intertropicale. Paris: Orstom. 559 pp.

Fenchel, T. (1987), Ecology of Protozoa. Madison: Science Tech Publishers. 197 pp.

Fernandez-Leborans, G.; Cordoba, M. J. H. and Del Arco, P. G. (1997), Distribution of ciliate epibionts on the portunid crab Liocarcinus depurator (Decapoda, Brachyura). Invert. Biol., 116 : (3), 171-177.

Foissner, W., Berger, H. and Schaumburg, J. (1999), Identification and ecology of limnetic plankton ciliates. Munich: Bavarian State Office for Water Management Munich Reports. v. 3. 793 pp.

Görtz, H. D. (1996), Symbiosis in ciliates. In: Hausmann, K. and Bradbury, P. C. (Eds.). Ciliates: cells as organisms. Stuttgart: Gustav Fischer. pp. 441-462.

Henebry, M. S. and Ridgeway, B. T. (1979), Epizoic ciliated protozoa of planktonic copepods and cladocerans and their possible use as indicators of organic water pollution. Trans. Am. Mic. Soc., 98 : (4), 495-508.

Lynn and Small, (2002), Phylum Ciliophora Doeflin, 1901. In: Lee, J. J.; Leedale, G. F. and Bradbury, P. C. (Eds.). An Illustrated Guide to the Protozoa. $2^{\text {nd }}$ ed. Lawrence: Allen Press. pp. 371-656.

Mayen-Estrada, R. and Aladro-Lubel M. A. (2001), Epibiont Peritrichids (Ciliphora: Peritrichida: Epistylidae) on the crayfish Cambarellus patzcuarensis in lake Pátzcuaro, Michoacán, Mexico. J. Crust. Biol., 21 : (2), 426-434.

Moss, A. G.; Estes, A. M.; Muellner,L. A. and Morgan, D. D. (2001), Protistian epibionts of the ctenophore Mnemiopsis mccradyi Mayer. Hydrobiologia, 451, 295-304. 
Puckett, G. L. and Carman, K. R. (2002), Ciliate epibiont effects on feeding, energy reserves, and sensitivity to hydrocarbon contaminants in an estuarine hapacticoid copepod. Estuaries, 25 : (3), 372-381.

Puytorac, P. (1994), Traité de zoologie. Tomo II: Infusoires ciliés. Paris: Masson. Fascicule 2: Systématique. 876 pp.

Sleigh, M. (1979), Biologia de los protozoos. Madrid: H. Blume. 399 pp.

Verni, F. and Guatieri P. (1997), Feeding behaviour in ciliated protists. Micron, 28 : (6), 487-504.

Received: February 17, 2005; Revised: August 10, 2005; Accepted: April 24, 2006. 